\title{
Research on Management Accounting Practice: A Network Teaching Model Guided by Practical Simulation
}

\author{
Zhuowen Huang, Ya Liu \\ Nanfang College of Sun Yat-sen University, Guangzhou, China \\ Email: happyhzw@hotmail.com
}

How to cite this paper: Huang, Z.W. and Liu, Y. (2020) Research on Management Accounting Practice: A Network Teaching Model Guided by Practical Simulation. Modern Economy, 11, 89-95. https://doi.org/10.4236/me.2020.111009

Received: December 6, 2019

Accepted: January 14, 2020

Published: January 17, 2020

Copyright (อ 2020 by author(s) and Scientific Research Publishing Inc. This work is licensed under the Creative Commons Attribution International License (CC BY 4.0).

http://creativecommons.org/licenses/by/4.0/

\section{(c) (i) Open Access}

\begin{abstract}
This paper uses a software system Enterprise Value Creation (EVC) as a basis for a reform of the new teaching method called Network Teaching Model of Accounting Management Practice. This study's purpose of cultivating such talents is to reform the existing management teaching model and establish a new application-oriented teaching model in order to achieve a win-win result. The study analyzes the course through EVC comparing the traditional teaching model to the network teaching model. The comparison of these two teaching methods indicates that reform is a trend and this course is highly applicable. Moreover, the study aims to mobilize the students' self-learning ability and enthusiasm for Accounting Management Practice by way of holding EVC actual competitions. The EVC systems allow the students the ability to solve a broader range of problems, while allowing the students the ability to learn more theories. The results indicate that network teaching model ultimately helps cultivate professional education, and apply innovation and entrepreneurial talents suitable for economic development. The aggregate results show that this course based on network teaching model can train people to possess practical talents with innovative thinking, entrepreneurial abilities, practical spirit, and adapting to social development. However, it is discovered upon implementation that two more modifications are necessary for its improvements. The current study gathered that applying such teaching method involving technological network concluded with students becoming more self-reliant and skilled in applying commerce-related work.
\end{abstract}

\section{Keywords}

Network Teaching Model, Management Accounting Practice, Enterprise Value Creation (EVC), Applied Innovation, Entrepreneurial Talents 


\section{Introduction}

A number of researchers have investigated that talent training should be given priority over competence and quality. For one, the International Association of Higher Business Schools (AACSB) considers professional ability, using dialectics to improve students' independence and critical thinking skills as the most important goals of business education [1] [2] [3] [4] [5]. Another has considered how the study of application-oriented management accounting teaching should be conceived, and applied in actual application, in order to guide the mixed management accounting teaching methods. This teaching methodology can be implemented in various scenarios such as in cooperation with enterprises, internships, experiments, and other task-driven methods. The said research emphasizes establishing a comprehensive teaching evaluation method that uses process control and fundamental theory applications to begin the implementation of the management accounting teaching model reform [6]. Moreover, some researchers found out that holding competitions can improve the students' learning efficiency and cultivate their self-learning ability. Taking into account the case of Tongji University's teaching center, it analyzes the effect of the competitions on improving the teaching quality of undergraduate education. In the end, results showed competitions enhance education reform [7]. In particular, a teaching model of Edith Cowan University in Western Australia aims to reform "modular" teaching content and implement "case teaching method with project-driven teaching method and scenario simulation teaching method". This variety of pedagogies has assisted them in the construction of curriculum designs, strengthening of teaching facilities security system, etc. [8]. However, those researches have not combined the network teaching model through studying accounting management practice with competitions. In addition, previous researches have exclusively focused on the theoretical importance of teaching reform excluding the benefits of learning through competition or vice versa.

The purpose of this paper explores the real-life benefits and feasibility of combining the new teaching model with competitions. This research will particularly use the teaching method utilized by Lu Huang in 2018 [9]. Furthermore, it implements the competition process previously mentioned by Xiaogang Wang, Dahong Yu, Xinhua Xu, Guoping Wang, Yajuan Fan in 2018 [7]. The aim of accounting management practice is to cultivate innovative and entrepreneurial talents in the context of network teaching model, which hopes to encourage students' enthusiasm via competitions to facilitate independent learning.

\section{The Teaching Research Ideas of Management Accounting Training under the Network Teaching Model}

An EVC teaching team needs to be set up to comprehensively discuss the design of the course content, the implementation of teaching plans, the selection of teaching methods, how to solve the problem of disconnected students' theoretical courses from practical training, and EVC competitions. Due to the innova- 
tion of the course teaching model, teaching information also involves a System support, which optimizes students' curriculum assessment mechanism and other issues.

The teaching plan of this course is shown in Table 1.

\section{Existing Problems in Promoting the Research of Traditional Management Accounting Practice under the Network Teaching Model}

At present, the State and Ministry of Education's policy of encouraging university students to innovate and start businesses is just a matter of traditional theoretical teachings, or simply participating in a competition to practice a project to achieve practical purposes, which are difficult to polish entrepreneurial talents. Afterward, systematic training, can improve the practical skills required at the theoretical level, which opens up the barriers of the course. This includes two levels of content, one is to strengthen the connection between the professional courses, and the other is to strengthen the hands-on experiences of students. In the study of multi-disciplinary theoretical knowledge, such as management accounting and financial accounting, there is a disconnection between theories and practical simulations, which makes it difficult for students to adapt what they have learned in real scenarios, making flexibility impossible. In order to solve the current situation and strengthen the comprehensive ability of students, EVC has been launched, which is a comprehensive course, however it has not yet formed a systematic system in teaching. So far, it has only conducted practical exploration of related competitions, and there is still much room for teaching improvement. At present, in order to better analyze the teaching mode of the EVC

Table 1. Teaching plan.

\begin{tabular}{|c|c|c|}
\hline Course Contents & Task & $\begin{array}{l}\text { Academic } \\
\text { Hour }\end{array}$ \\
\hline Introduction & $\begin{array}{l}\text { Introduce system functions, features, processes, and complete } \\
\text { tasks in groups with different roles (Group of } 4 \text { ) }\end{array}$ & 1 \\
\hline Exercise & $\begin{array}{l}\text { Introduce the functions of the system and explain the rules in } \\
\text { Actual Competition Simulation }\end{array}$ & 2 \\
\hline Theories & $\begin{array}{l}\text { Introduce the Theories that support the Actual Competition } \\
\text { Simulation }\end{array}$ & 11 \\
\hline $\begin{array}{l}\text { Competition } \\
\text { Experience }\end{array}$ & $\begin{array}{l}\text { Individually complete two periods of operation, become familiar } \\
\text { with the platform functions and rules, analyze short-term } \\
\text { business planning performances }\end{array}$ & 3 \\
\hline $\begin{array}{l}\text { Actual Competition } \\
\text { Simulation (1) }\end{array}$ & Start to run the first round of confrontation ( 6 periods) & 8 \\
\hline $\begin{array}{l}\text { Actual Competition } \\
\text { Simulation (2) }\end{array}$ & Start to run the second round of confrontation (10 periods) & 8 \\
\hline \multirow[t]{2}{*}{ Presentation } & $\begin{array}{l}\text { Groups report their case analysis combined with their practical } \\
\text { experiences }\end{array}$ & 3 \\
\hline & Total & 36 \\
\hline
\end{tabular}


course, the online EVC training operation platform developed by NetChina.com is used in conjunction with the school's basic teaching equipment to provide a solid foundation for its smooth implementation.

1) How to transition from traditional teaching to the new teaching model

Teachers need to abandon the dominant position in traditional teaching and renew teaching concepts. Teachers need to create a relaxed and free atmosphere for students, make reasonable use of the diverse and information-based teaching methods of "give + participation + guidance", and enrich competition cases. Practice cases are integrated into the student's learning process, allowing students to participate fully in classroom teaching, research and explore problems, and to find solutions. At the same time, educators need to engage in interactive discussions with students through actual training in the mall, update the knowledge structure in real time, expand horizons and teaching ideas, keep up with cutting-edge information, and improve teaching capabilities.

Li Xiaomei, Liu Xiaowei, He Kui (2018) referenced from the teaching model of Edith Cowan University in Western Australia, and aimed at reforming "modular" teaching content and implementing "case teaching method with project-driven teaching method and scenario simulation teaching method". This variety of teaching methods have assisted them in the construction of curriculum designs, and strengthening of teaching facilities security system, etc. Currently, the situation of students' theoretical study and actual operation are completely separated. Several theoretical studies are confusing, leading to the delay of the actual operation. Our reforms focus on having the theoretical knowledge to be applied in practical training, so that students can learn to use them, and verify their usefulness through the actual practices. In addition, using the training platform provides students with a timely resource platform to consolidate theoretical knowledge and build a knowledge system.

\section{2) Can the network teaching stimulate students' enthusiasm?}

Taking the Internet operation platform as a carrier, it simulates the entrepreneurial process, integrates professional knowledge into the entire business warfare exercise platform, and realizes "inspiring entrepreneurial awareness, experiencing the entrepreneurial process, and improving entrepreneurial skills" in participation, and effectively improving students' ability to analyze and solve practical problems. So far, the EVC management accounting training platform is a platform system for simulating entrepreneurship and a teaching tool.

Through the use of the intelligent system in the classroom-the "Teacher", which is the system will automatically issue financial external reports after each operation, such as balance sheets, profit statements, cash flow statements, as well as production cost details, period expense details, and cash. Especially, the cash flow statement helps students understand the financial status of the company, and automatically calculates the financial report analysis indicators, and uses chart tools, such as radar charts and DuPont analysis for financial analysis. Once the process is done, the instructor will comment and analyze the students' com- 
panies to develop their business acumen and data analysis capabilities. This is equivalent to a tool for auxiliary teaching, which stimulates students' consciousness of active learning and exploration.

3) How does the network teaching model cultivate innovative and entrepreneurial talents?

Based on the EVC training platform, it helps cultivate innovative and entrepreneurial talents for students, and organically integrates the advantages of modern information education and traditional education. Additionally, it also improves the learning efficiency of students while improving teaching efficiency, and explores the issues of "what to learn" and "how to learn". The instructors will also organize students to carry out business-based adversarial learning on their own, establish interactive discussion groups offline, discuss competition strategies, summarize experiences, and combine online and offline learning. With EVC, it will break the limitations of students passively accepting whatever information educators teach them in classroom settings. As a result, it will strengthen the students' autonomous learning consciousness and exercise self-education and application of technical skills through competitions supported by Internet technology.

\section{Future Improvement Plan}

For the EVC management accounting training platform, it is a scenario simulation. By designing an operating environment similar to that in real life, students are allowed to enter a scenario, play various roles, and conduct simulation exercises to better understand and master what they have learned. This is a teaching method that enhances knowledge and improves practical ability. However, in the course of the research, we found some areas for improvements.

1) Optimize assessment methods to solve students' learning attitude in the new model

Based on mobilizing students' enthusiasm for the curriculum, the following assessment methods were made, as shown in Table 2 and Table 3.

2) Promote learning by competition and improve the combination of theoretical and practical lessons

Through the EVC management accounting training platform as the main body, practical operation simulation as the guide, and the talent entrepreneurship training model combined with the competition, it is an organic combination of

Table 2. General assessment methods.

\begin{tabular}{ccc}
\hline Content of the examination & Task & Points \\
\hline Self-learning & Class discussion and operational analysis & 30 \\
Process learning & Practical experiment report and case analysis presentation. & 30 \\
& Each group discusses the outcome & \\
Hands-on exercise & Simulation of actual competition system & 40 \\
& Total & 100 \\
\hline
\end{tabular}


Table 3. Specific assessment methods in actual competition.

\begin{tabular}{ccc}
\hline $\begin{array}{c}\text { Content of the } \\
\text { examination }\end{array}$ & Task & Points \\
\hline $\begin{array}{c}\text { Actual Competition } \\
\text { Simulation (1) }\end{array}$ & $\begin{array}{l}\text { Start to run the first round of confrontation (6 periods): Analysis of the } \\
\text { implementation of the medium-term business plan (2 persons/group) }\end{array}$ & 40 \\
$\begin{array}{c}\text { Actual Competition } \\
\text { Simulation (2) }\end{array}$ & $\begin{array}{l}\text { Start to run the second round of confrontation (10 periods): Analysis } \\
\text { of the implementation of long-term business plan (4 persons/group) }\end{array}$ & 60 \\
& Total & 100 \\
\hline
\end{tabular}

the needs of university students for the cultivation of talents under the trend of innovative entrepreneurship. The EVC management accounting training teaching is a combination of theoretical courses and practical teaching to cultivate students' practical skills, management execution ability, and management decision-making ability. This is a kind of talent training model formed under the direction of network teaching model under the environment of big data and information technology. And through EVC training to simulate the actual business environment of the company, allowing students to give full play to their role in role-playing to make the company's business decision-making work, so that it can form a strong business concentration, market response, and value creation ability, towards knowledge, ability, thinking, and other diversified "composite" talents.

It is a project-driven model to promote student learning through competitions. Students participate in competitions, and use platform training in class. During competitions, they set different goals, and try different solutions to derive the most profitable entrepreneurial model. This solves the phenomenon of students' separation of theory and practice in the learning process, leading to the cultivation of students' comprehensive creative thinking ability and interest in entrepreneurship.

\section{Conclusion}

At present, the study of management accounting training teaching mode oriented by practical simulation under the network teaching model is to change the psychology of students relying on educators to teach knowledge in the classroom. The concept of network teaching model and the promotion of learning through competition pass on to students, guide them to turn to independent inquiry learning, teamwork collaborative learning, form and strengthen self-learning consciousness, improve self-learning ability, innovation and entrepreneurship ability, application ability, and cultivate strategic thinking.

\section{Conflicts of Interest}

The authors declare no conflicts of interest regarding the publication of this paper.

\section{References}

[1] Accounting Education Change Commission (AECC) (1990) Objectives of Educa- 
tion for Accountants: Position Statement No.1. Issues in Accounting Education, 5, 307-312.

[2] Albrecht, W.S. and Sack, R.J. (2001) The Perilous Future of Accounting Education. CPA Journal, 71, 16-23.

[3] Howieson, B. (2003) Accounting Practice in the New Millennium: Is Accounting Education Ready to Meet the Challenge? The British Accounting Review, 35, 69-103. https://doi.org/10.1016/S0890-8389(03)00004-0

[4] Barrie, S.C. (2004) Understanding What We Mean by the Generic Attributes of Graduates. Higher Education, 51, 215-241.

https://doi.org/10.1007/s10734-004-6384-7

[5] He, Y.R. and Li, X.H. (2013) Research on the Accounting Talents Training Model in Chinese Universities-Based on Field Investigation of Accounting Education in Ten American Universities. Accounting Research, No. 4, 26-31.

[6] Wei, Y.P. (2015) Research on Application Ability-Oriented Teaching Mode of Management Accounting. Proceedings of 2015 International Conference on Education Research and Reform (ERR2015 V9), 21 April 2015, 7.

[7] Wang, X.G., Yu, D.H., Xu, X.H., et al. (2018) Promoting the Teaching Reform of Chemical Experiments with the Subject Competition as the Handle. Laboratory Research and Exploration, 37, 198-201.

[8] Li, X.M., Liu, X.W. and He, K. (2018) Research and Practice on Teaching Reform of Business Administration Courses under the Background of "Internet + Education". Heilongjiang Education (Higher Education Research and Evaluation), 1254, 7-8.

[9] Huang, L. (2018) New Exploration of Teaching Design in Information Colleges and Universities-Taking the Course of "Financial Law and Accounting Professional Ethics" as an Example. Economist, 351, 199-200. 